Journal of Technology and Social for Community Service (JTSCS)

Vol. 2, No. 2, September 2021, page-page. 63 71

P-ISSN: 2723-455X

E-ISSN: 2723-2026

available online at: https://ejurnal.teknokrat.ac.id/index.php/teknoabdimas

\title{
PENERAPAN AUTO PUMP HAND SANITIZER BERBASIS IOT UNTUK PENINGKATAN KOMPETENSI SISWA SMK GAJAH MADA BANDAR LAMPUNG
}

\author{
Auliya Rahman Isnain ${ }^{1}$, Sanriomi Sintaro ${ }^{2}$, Fenty Ariany $^{3}$ \\ Informatika, Fakultas Teknik dan Ilmu Komputer, Universitas Teknokrat Indonesia ${ }^{\mathbf{1 , 3}}$ \\ Teknik Komputer, Fakultas Teknik dan Ilmu Komputer, Universitas Teknokrat Indonesia ${ }^{2}$
}

Email : auliyarahman@teknokrat.ac.id ${ }^{1}$, sanriomi@teknokrat.ac.id ${ }^{2}$, fentyariany@teknokrat.ac.id ${ }^{3}$

\begin{abstract}
Received: (5 Agustus 2021)
Accepted: (28 Agustus 2021)

Abstract

Gajah Mada SMK Bandar Lampung, initially named SMEA Gajah Mada with the Decree of the Minister of Education and Culture of the Republic of Indonesia No. 4111/12B/4/1990 with REGISTERED status, which is located at Jalan Soekarno Hatta No.1 Tanjung Happy Village, Tanjung Glad District, The city of Bandar Lampung then in 1990 had the status of RECOGNIZED, and in 2006 its status became ACCREDITED with two majors, namely Accounting and received a $B$ value and Office Administration received a $C$ value. (Marketing) and has been completed with a grade of "Accredited B" while the Computer and Network Engineering major was only opened in the 2014/2015 Academic Year. The manufacture of Arduino UNO-based Auto-Pump Hand Sanitizer is an initiative activity of lecturers and students of the Indonesian Technocrat University as a form of real contribution to the people of Bandar Lampung City, especially at SMK Gajah Mada Bandarlampung. Auto-Pump Hand Sanitizer (APHS) Able to work automatically to remove Hand Sanitizer liquid when you bring your palms closer to APHS.
\end{abstract}

Published : (15 September 2021)

Keywords: Auto, Pump, SMK, Arduino Uno, Hand Sanitizer

\begin{abstract}
Abstrak
SMK Gajah Mada Bandar Lampung, awal berdirinya bernama SMEA Gajah Mada dengan SK Menteri Pendidikan dan Kebudayaan Republik Indonesia No.4111/12B/4/1990 dengan status TERDAFTAR, yang berada dilokasi Jalan Soekarno Hatta No.1 Kelurahan Tanjung Senang, Kecamatan Tanjung Senang, Kota Bandar Lampung kemudian pada tahun 1990 berstatus DIAKUI, dan pada tahun 2006 statusnya menjadi TERAKREDITASI dengan dua jurusan yaitu Akuntansi mendapat nilai B dan Administrasi Perkantoran mendapat nilai C Kemudian pada tahun 2010 SMK Gajah Mada telah melaksanakan akreditasi ulang untuk jurusan Akuntansi, Administrasi Perkantoran dan Pemasaran (Marketing) dan telah selesai dengan nilai "Terakreditasi B" sedangkan untuk jurusan Teknik Komputer dan Jaringan baru dibuka pada Tahun Pelajaran 2014/2015. Pembuatan Auto-Pump Hand Sanitizer berbasis Arduino UNO ini merupakan kegiatan inisiatif dari Dosen dan mahasiswa Universitas Teknokrat Indonesia sebagai bentuk kontribusi nyata untuk Masyarakat Kota Bandar Lampung Khususnya pada SMK Gajah Mada Bandarlampung. Auto-Pump Hand Sanitizer (APHS) Mampu bekerja secara otomatis untuk mengeluarkan cairan Hand Sanitizer ketika mendekatkan telapak tangan ke arah APHS.
\end{abstract}

Kata Kunci: Auto, Pump, SMK, Arduino Uno, Hand Sanitizer

\section{To cite this article:}

Auliya Rahman Isnain, Sanriomi Sintaro, Fenty Ariany. (2021). PENERAPAN AUTO PUMP HAND SANITIZER BERBASIS IOT UNTUK PENINGKATAN KOMPETENSI SISWA SMK GAJAH MADA BANDAR LAMPUNG. Journal of Technology and Social for Community Service (JTSCS), Vol(2), 63-71. 


\section{PENDAHULUAN}

\subsection{Analisis Situasi}

Sekolah adalah lembaga pendidikan formal yang bertanggungjawab atas pendidikan siswa. Salah satu komponen sentral dalam sekolah adalah guru. Guru menjadi pendidik dengan fungsi utama mengajar dan mencerdaskan peserta didik. (Riskey Oktavian, 2020)

Guru juga bertanggungjawab terhadap nilai-nilai etis dan ilmu-ilmu yang diajarkan. Nilai-nilai tersebut diantaranya: (1) nilai kebenaran, (2) nilai keindahan, dan (3) nilai kebaikan. Sedangkan tugas mengajar adalah suatu aktivitas intensional yaitu suatu aktivitas yang menimbulkan belajar. Di dalam proses pembelajaran terjadi interaksi antara berbagai komponen pembelajaran. Komponen-komponen itu dapat dikelompokkan ke dalam tiga kategori utama, yaitu guru, isi atau materi pembelajaran dan siswa. Interaksi antara ketiga komponen utama melibatkan sarana dan prasarana, seperti metode pembelajaran, media pembelajaran, dan penataan lingkungan tempat belajar, sehingga tercipta situasi pembelajaran yang memungkinkan tercapainya tujuan yang telah direncanakan sebelumnya. Dengan demikian, guru memegang peranan sentral dalam proses pembelajaran (Riskey Oktavian, 2020)

Sesuai dengan tujuan pendidikan nasional, yaitu ikut mencerdaskan bangsa dan mengembangkan manusia Indonesia yang utuh, yaitu manusia yang beriman dan bertaqwa kepada Tuhan Yang Maha Esa dan berbudi pekerti luhur, memiliki pengetahuan dan keterampilan, kesehatan jasmani dan rohani, kepribadian yang mantap dan mandiri, serta rasa tanggung jawab kemasyarakatan dan kebangsaan,Maka berdasarkan hal tersebut di atas Yayasan Pendidikan Gajah Mada Bandar Lampung, khususnya SMK Gajah Mada, ikut terpanggil untuk melaksanakan pencapaian tujuan pendidikan nasional tersebut (Mada, 2020)

SMK Gajah Mada Bandar Lampung, awal berdirinya bernama SMEA Gajah Mada dengan SK Menteri Pendidikan dan Kebudayaan Republik Indonesia No.4111/12B/4/1990 dengan status TERDAFTAR, yang berada dilokasi Jalan Soekarno Hatta No.1 Kelurahan Tanjung Senang, Kecamatan Tanjung Senang, Kota Bandar Lampung kemudian pada tahun 1990 berstatus DIAKUI, dan pada tahun 2006 statusnya menjadi TERAKREDITASI dengan dua jurusan yaitu Akuntansi mendapat nilai B dan Administrasi Perkantoran mendapat nilai C Kemudian pada tahun 2010 SMK Gajah Mada telah melaksanakan akreditasi ulang untuk jurusan Akuntansi, Administrasi Perkantoran dan Pemasaran (Marketing) dan telah selesai dengan nilai "Terakreditasi B" sedangkan untuk jurusan Teknik Komputer dan Jaringan baru dibuka pada Tahun Pelajaran 2014/2015.

Sejak berdirinya SMK Gajah Mada dari tahun 1987 sampai sekarang ini telah mengalami pergantian kepala sekolah tiga kali, yaitu:

1. Pada Tahun 1987 sampai dengan 2007 adalah Bapak Drs. Ragil Sukadis,

2. Pada Tahun 2007 sampai 2014 adalah Bapak Maryadi Saputra, S.E., M.M.,

3. Pada Tahun 2014 sampai sekarang adalah Ibu Enden Sopa Sopiyana, S.Sos., M.Pd.

Sampai saat ini SMK Gajah Mada Bandar Lampung telah memiliki gedung berlantai 3 dengan sarana lapangan olah raga, halaman parkir, kantin sekolah, studio musik, ruang komputer, laboratorium, perpustakaan, musholah, dan lain-lain, dengan jumlah rombel sebanyak 20 kelas.

Untuk sarana dan prasaran SMK Gajah Mada Bandarlampung sudah mencukupi, namun dimasa pandemi covid-19 ini pihak sekolah masih belum membuka sekolah untuk proses kegiatan belajar mengajar. Proses belajar dan mengajar dan kegiatan lainnya masih dilakukan secara daring. Namun demikian untuk para guru yang ada jadwal mengajar diwajibkan untuk hadir kesekolah. Dengan demikian SMK Gajah Mada Tidak 100\% menutup sekolah mereka dari kegiatan.

\subsection{Permasalahan Mitra}

Untuk terus melakukan kegiatan belajar dan mengajar SMK Gajah Mada telah menerapakan sistem pembelajaran dalam jaringan dengan menggunakan Google Classroom dan berbagai platform lainnya. Akan tetapi guru yang mengajar siswa dalam jaringan tetap diwajibkan untuk hadir di sekolah. Dimasa pandemi covid-19 ini rentan sekali penularan yang terjadi jika ada kerumunan dan perkumpulan dalam satu ruangan (Herbert, 2021). Akan tetapi pihak sekolah SMK Gajah Mada Telah memiliki sarana dan prasarana Protokol kesehatan yang memadai. Seperti menyiapkan handsaitizer, tempat cuci tangan dan alat pengecekan suhu tubuh. Namun Protokol kesehatan yang disiapkan masih manual, untuk itu diperlukan suatu alat yang bisa otomatis tanpa disentuh oleh tangan pengguna, sehingga penularan virus pun akan semakin berkurang. 
Berdasarkan hasil pengamatan, diskusi dan pengumpulan kebutuhan yang tim pengusul lakukan dengan mitra, pihak mitra yaitu SMK Gajah Mada Bandarlampung mengusulkan untuk membuat Auto-Pump Hand Sanitizer kepada tim pengusul PKM Universitas Teknokrat Indonesia yang dapat mengatasi permasalahan yang telah dijelaskan. Pihak sekolah berharap dengan adanya Auto-Pump Hand Sanitizer dapat mencegah menularnya virus sehingga pihak sekolahpun akan jauh lebih siap apabila pemerintah mengelurkan surat edaran membuka kembali kegiatan di sekolah dan siswa pun akan jauh lebih tenang jika semua sarana dan prasaran protokol kesehetan sudah memadai. Dengan adanya kerjasama ini pihak sekolah ingin siswa mereka juga mampu membuat alat yang serupa sebagai bekal untuk meningkatkan kemampuan siswa mereka. Hal ini dapat diwujudkan oleh tim pengusul dalam bentuk pelatihan yang akan diberikan kepada siswa SMK Gajah Mada Bandarlampung.

\section{METODE PELAKSANAAN}

\section{Tempat dan Waktu}

Tempat pelaksanaan kegiatan dilakukan di ruang pertemuan SMK Gajah Mada Bandar Lampung yang di hadiri oleh 30 siswa Jurusan TKJ SMK Gajah Mada Bandar Lampung. Kegiatan ini berlangsung selama 120 menit.

\section{Khalayak Sasaran}

Sasaran Kegaian PkM Sekolah Binaan ini adalah siswa kelas 12 Jurusan TKJ SMK Gajah Mada

\section{Tahapan Pembuatan Alat}

Auto Pump Hand Sanitizer dirancang menggunakan metode embedded sistem, adapun tahapan dalam rancangan meliputi:

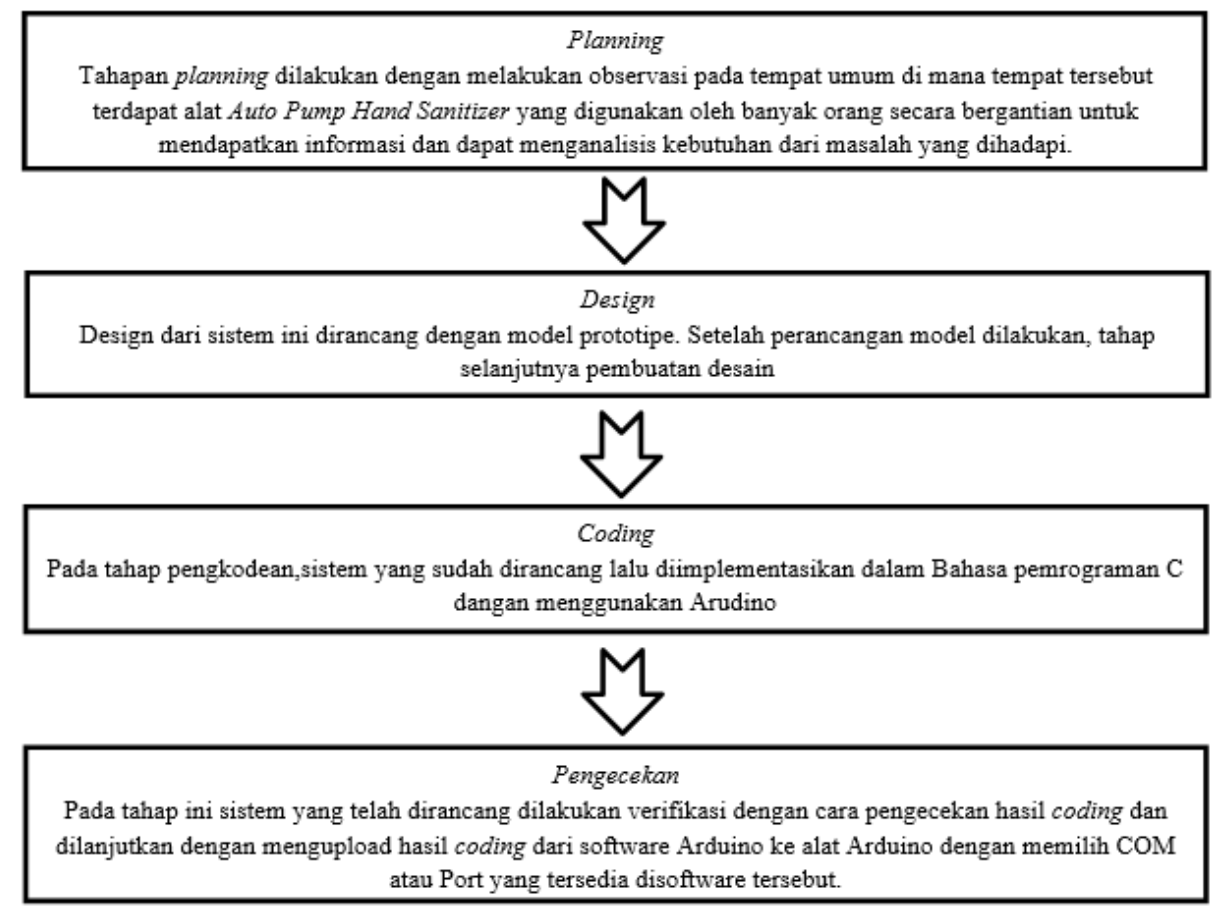

Gambar 1 Bagan Tahapan Pembuatan Alat

1. Pengumpulan Data

Observasi/pengamatan adalah salah satu proses pengumpulan data di mana seorang peneliti melakukan pengamatan pada masyarakat yang menjadi objeknya(Amarudin et al., 2020). Teknik observasi didasarkan atas pengalaman secara langsung karena seorang peneliti dapat melihat dan mengamati sendiri dan mencatat kejadian pada keadaan sebenarnya(Ahdan \& Setiawansyah, 2021). 
2. Desain

Dalam perancangan Auto Pump Hand Sanitizer menggunakan perangkat keras sebagai berikut :

1. Arduino Uno R3 sebagai pengendali utama.

2. Sensor Ultrasonik sebagai pendeteksi jarak benda

3. Dinamo sebagai pompa air

4. Relay 1 chanel sebagai saklar arus DC

5. Adaptor 5V sebagai pensuplay daya.

Adapun bahan-bahan pendukung untuk membangun Auto Pump Hand Sanitizer adalah sebagai berikut :

1. Pipa pve : digunakan untuk pembuatan penyangga Auto Pump Hand Sanitizer dan untuk tempat mengalirnya air.

2. Akrilik : digunakan sebagai penutup pada bagian atas agar cahaya matahari tidak mengenai sensor secara langsung.

3. Box : digunakan untuk meletakan komponen-komponen agar terhindar dari cipratan air.

Prinsip kerja Auto Pump Hand Sanitizer adalah dengan memanfaatkan sensor ultrasonik yang akan mendeteksi jarak tangan dan akan mengirimkan perintah ke arduino yang sebelumnya sudah diupload logika perintah-perintah, arduino akan memberi perintah ke motor listrik yang bekerja sebagai pemompa hand sanitizer.

3. Coding

Karena Auto Hand Sanitizer menggunakan Arduino yang di program dengan Bahasa C melalui software Arduino IDE.

Sensor ultrasonik hanya bisa mengenali jarak pantulan benda yang ada di depannya, sensor mengirimkan data jarak pada arduino kemudian dikonversi ke satuan $\mathrm{cm}$. Setelah jarak diketahui maka data jarak dari sensor akan di bandingkan dengan data jarak yang sudah ditetapkan pada program(Samsugi \& Wajiran, 2020). Berikut gambar cara kerja sensor ultrasonik yang mendeteksi tangan

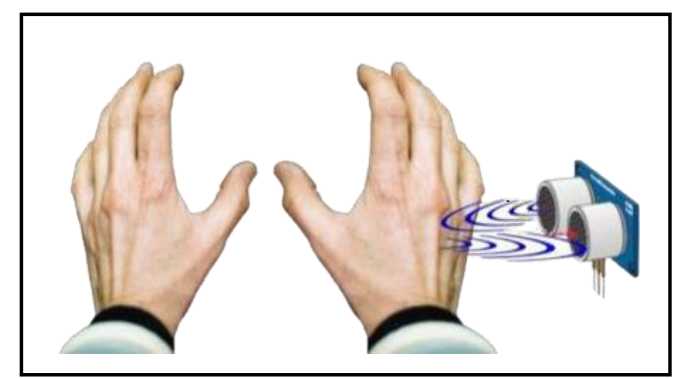

Gambar 2. Sensor Ultrasonik mendeteksi tangan

Sensor ultrasonik diletakan pada sisi depan alat, cara kerjanya sensor ultrasonik akan memancarkan gelombang suara ke permukaan tangan yang kemudian gelombang akan memantul kembali ke sensor dan akan memberikan perintah ke arduino. Namun jika tangan tidak ada (tidak terdeteksi) maka gelombang dari sensor tidak akan dipantulkan karena sudah ditentukan jarak pantul gelombang kurang dari sama dengan $5 \mathrm{~cm}$ maka APHS akan berhenti dan masuk ke mode standby.

\section{HASIL DAN PEMBAHASAN}

Berdasarkan hasil survey awal yang dilakukan sebelum pelaksanaan pelatihan dimulai dan setelah kegiatan pelatihan dengan menyebarkan kuesioner menunjukan bahwa siswa SMK Gajah Mada Bandar Lampung menjadi lebih memahami dan dapat membuat alat Auto Pump Hand Sanitizer Berbasis IoT. Tabel Peningkatan Indikator Penilaian dapat dilihat pada Tabel 1:

Tabel 1 Peningkatan Indikator Penilaian Kuesioner 


\begin{tabular}{|l|l|l|l|}
\hline \multirow{2}{*}{ No } & \multicolumn{1}{|c|}{ Pernyataan } & \multicolumn{2}{c|}{ Nilai } \\
\cline { 3 - 4 } & & \multicolumn{1}{c|}{ Sebelum } & Sesudah \\
\hline 1. & Saya sudah dilatih untuk membuat alat auto pump handsatizer & 0,36 & 1 \\
\hline 2. & Saya sudah mengetahui alat Arduino Uno R3 dan fungsinya & 0,43 & 0,86 \\
\hline 3. & Saya sudah mengetahui alat Sensor Ultrasonik sebagai pendeteksi jarak benda & 0,57 & 0,93 \\
\hline 4. & Saya sudah mengetahui alat Dinamo sebagai pompa air & 0,57 & 0,93 \\
\hline 5. & Saya sudah Mengetahui alat Relay 1 chanel sebagai saklar arus DC & 0,36 & 0,79 \\
\hline 6. & Saya sudah mengetahui alat Adaptor 5V sebagai pensuplay daya. & 0,50 & 0,86 \\
\hline
\end{tabular}

Berdasarkan Tabel 5, rata-rata penilaian tiap indikator dari pelatihan penggunaan Auto Pump Hand Sanitizer mengalami peningkatan dari rata-rata 0,49 meningkat menjadi 0,90. Peningkatan nilai rata-rata sebelum dan sesudah dilaksanakan pelatihan sebesar 0,43 . Untuk alat yang di buat dapat dilihat pada gambar berikut:
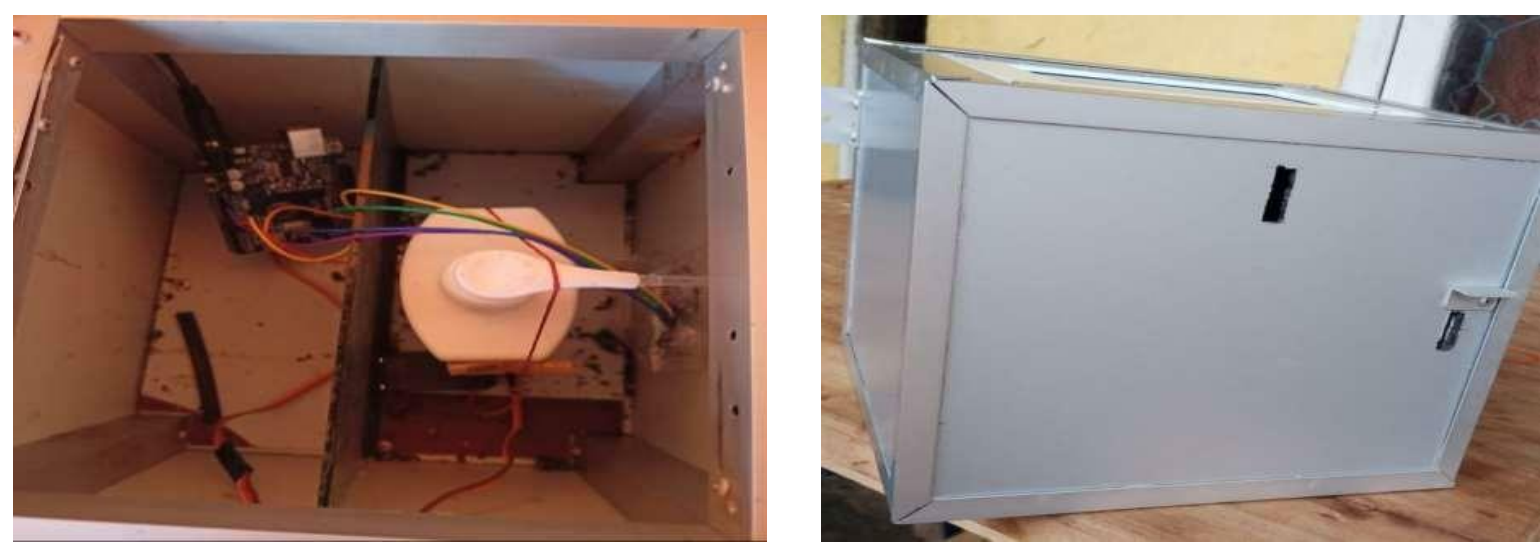

Gambar 3. Contoh Auto Pump Hand Sanitizer

Pada Gambar 3 merupakan alat Auto Pump Hand Sanitizer yang pernah dikembangkan oleh tim pengusul dan akan menjadi langkah awal dalam membuat dan mengembangkan Auto Pump Hand Sanitizer dan Pengecekan suhu Otomatis berikutnya.

\section{KESIMPULAN}

Secara umum, kegiatan PKM Sekolah Binaan yang lakukan di SMK Gajah Madah Bandarlampung telah terlaksana dengan baik. Dengan adanya kegiatan ini dapat memperkenalkan Universitas Teknokrat Indonesia kepada sekolah tujuan PKM Sekolah Binaan.

\section{UCAPAN TERIMA KASIH}

Terima kasih diucapkan penulis pada Universitas Teknokrat Indonesia (UTI) melalui Lembaga Penelitian dan Pengabdian kepada Masyarakat (LPPM) karena berkat hibah internalnya dengan nomor kontrak 118/UTI/LPPM/E.1.8/III/2021 tanggal 1 Maret 2021, pelaksanaan kegiatan PkM di SMK Gajah Mada ini dapat terlaksana dengan baik dan lancar. Selain itu, penulis juga mengucapkan terima kasih kepada mitra PkM, keluarga besar SMK Gajah Mada Bandar Lampung. Berkat dukungan dari mitra dan semangat dari guru-guru SMK Gajah Mada Bandar Lampung, kegiatan peningkatakan kompetensi pelatihan pembuatan alat 
auto pomp hand sanitizer ini dapat terlaksana dengan baik dengan menghasilkan luaran sesuai target. Semoga kegiatan ini dapat bermanfaat bagi seluruh pihak yang terlibat, baik secara langsung maupun tidak langsung.

\section{REFERENSI/DAFTAR PUSTAKA}

Ahdan, S., \& Setiawansyah, S. (2021). Android-Based Geolocation Technology on a Blood Donation System (BDS) Using the Dijkstra Algorithm. IJAIT (International Journal of Applied Information Technology), 115.

Amarudin, A., Saputra, D. A., \& Rubiyah, R. (2020). Rancang Bangun Alat Pemberi Pakan Ikan Menggunakan Mikrokontroler. Jurnal Ilmiah Mahasiswa Kendali Dan Listrik, 1(1), 7-13.

M. Cristy Pane, "Virus Corona," https://www.alodokter.com/, 2020.

M. M. Srihari, "Self-Activating Sanitizer With Battery Imposed System For Cleansing Hands," 2020 Second International Conference on Inventive Research in Computing Applications (ICIRCA).

R. Oktavian and R. F. Aldya, "Efektivitas Pembelajaran Daring Terintegrasi di Era Pendidikan 4.0," Didakt. J. Pendidik. dan Ilmu Pengetah., vol. 20, no. 2, 2020.

Samsugi, S., \& Wajiran, W. (2020). IOT: Emergency Button Sebagai Pengaman Untuk Menghindari Perampasan Sepeda Motor. Jurnal Teknoinfo, 14(2), 99-105.

T. N. I. Zulva, "Covid-19 Dan Kecenderungan Psikosomatis," J. Chem. Inf. Model., 2020, doi: 10.1017/CBO9781107415324.004.

WHO, “COVID-19 COVID-19,” WHO J. covid 19, Reg. Situational Updat. Africa, 2020. 


\section{LAMPIRAN}

- Dokumentasi Kegiatan

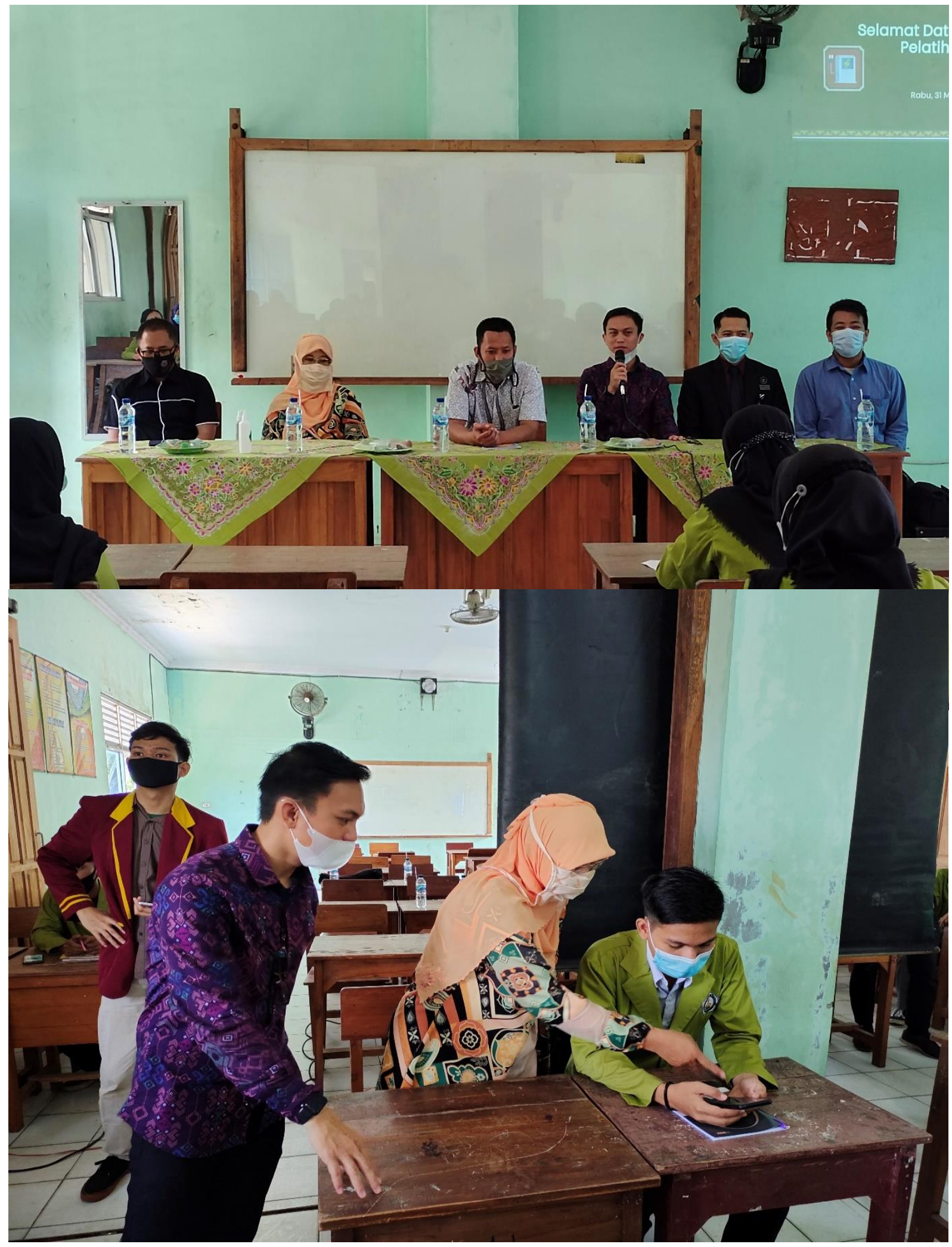




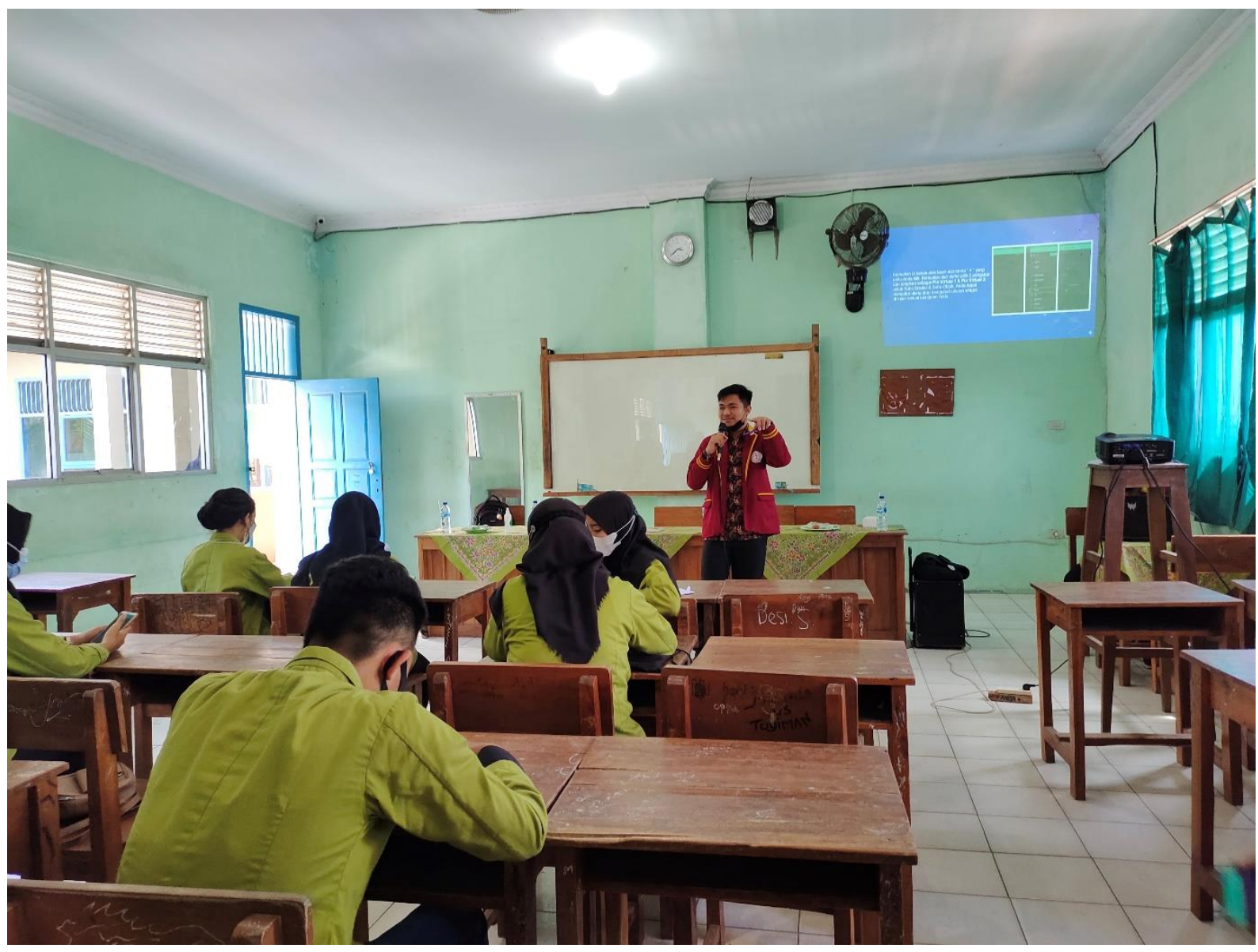




\section{BIOGRAFI PENULIS}

Auliya Rahman Isnain, S.Kom., M.Cs.
Penulis lahir di Muara Dua pada tahun 1992. Lulus pada Program Studi S1 Sistem Informasi
STMIK Teknokrat Lampung pada tahun 2015. Kemudian menyelesaikan pendidikan S2 Magister
Ilmu Komputer pada bidang Data Science di Universitas Gadjah Mada Yogyakarta pada Tahun
2020, dan saat ini sedang aktif mengajar di Universitas Teknokrat Indonesia. Minat bidang
penelitian penulis adalah Data Science, Data Mining dan Text Mining.

